\title{
O Legado Político de Platão sob o Olhar Liberal de Karl POPPER: Discussóes EM TORNO dO Advento de Regimes Democrático-Autocráticos
}

\author{
Loiane Prado Verbicaro* \\ André Silva Oliveira**
}

\begin{abstract}
1 Introdução. 2 As principais diretrizes do pensamento de Platão: um projeto autoritário? 3 As críticas liberais de Karl Popper ao programa político de Platão. $4 \mathrm{O}$ advento de regimes híbridos e o legado platônico. 5 Conclusão. Referências.
\end{abstract}

\section{RESUMO}

$\mathrm{Na}$ literatura em filosofia, teoria política e outros campos afins do conhecimento em ciências humanas e sociais, permanece inconclusiva a discussão sobre a natureza do legado político deixado por Platão. Para alguns autores, como Karl Popper, o pensamento platônico exibe indiscutíveis elementos autoritários, a ponto de influenciar decisivamente uma tradição coletivista que se contrapõe ao individualismo democrático, pedra de toque das democracias representativas de tipo liberal. Após o fim da Guerra Fria, assistiu-se ao advento dos chamados regimes híbridos ou iliberais, trazendo de volta ao debate acadêmico aspectos normativos das críticas liberais endereçadas à tradição influenciada pelo pensamento político de Platão. $\mathrm{O}$ trabalho, por intermédio de pesquisa bibliográfica de abordagem qualitativa, tem por objetivo discutir e revisitar a literatura para atualizar o debate sobre o legado do coletivismo platônico, tendo como referencial teórico o pensamento liberal de Karl Popper e a emergência dos regimes híbridos (democrático-autoritários). A conclusão principal é a de que a tensão entre o coletivismo de recorte platônico e o individualismo democrático, típico do liberalismo, permanece atual como se pode observar pelos choques entre regimes híbridos e democracias liberais.

Palavras-chave: Platão. Totalitarismo. Popper. Liberalismo. Regimes Híbridos.

\section{INTRODUÇÃO}

No final do século XX, a queda do muro de Berlim e o colapso do comunismo soviético constituíram-se em eventos históricos que sugeriram o triunfo aparente do liberalismo. Todavia, a ideia de um historicismo liberal afigura-se equivocada, considerando que a tradição

* Doutora em Filosofia do Direito pela Universidade de Salamanca, Mestre em Direitos Fundamentais e Relações Sociais pela Universidade Federal do Pará, Mestre em Ciência Política pela Universidade Federal do Pará, Coordenadora e Professora da Graduação e do Mestrado em Direito do Centro Universitário do Pará. Graduanda em Filosofia na Universidade Federal do Pará. Líder do Grupo de Pesquisa (CNPQ): Democracia, Poder Judiciário e Direitos Humanos. <Email: loianeverbicaro@uol.com.br>.https://orcid.org/0000-0002-3259-9906

** Doutor em Ciência Política (UFPE). Mestre em Ciência Política (UFPA). Especialista em Direito Público (FAP). Graduado em Direito (UFPA). Email: < bandarraportugal@ig.com.br>. https://orcid.org/0000-0002-8918-2845 
liberal não admite a inexorabilidade de um sentido (ou caminho) único para a trajetória da história. Apenas alguns anos depois do fim da Guerra Fria, assistiu-se ao advento das chamadas democracias iliberais. No século XXI, em um cenário de desdemocratização ou de enfraquecimento das democracias contemporâneas, ainda que sob o verniz democrático, como nos alerta Tilly (2013), a literatura identificou a emergência de regimes políticos que mesclam, simultaneamente, traços autoritários e democráticos, sendo nominados de regimes híbridos cujo escopo se contrapõe à manutenção, à consolidação e ao aprimoramento das instituições típicas da democracia representativa de tipo liberal.

As ideias centrais que justificam a implantação e a vigência dos regimes híbridos guardam conexão com o pensamento político de Platão, desvelando a permanência do seu ideal coletivista. Isso porque, segundo a perspectiva popperiana, o filósofo teria inaugurado uma tradição política que serviria de fundamento para a atuação das forças de uma sociedade fechada, com nítido caráter totalitário, que pretende controlar os processos históricos, diferentemente dos defensores da sociedade aberta que acreditam que, por meio do uso da razão crítica, as instituições democráticas necessitam de reformas contínuas para se adaptarem às mudanças sociais sem a pretensão de subjugar a trajetória do curso da história.

Em "A República", Platão (2000) reserva o exercício do poder político aos filósofos, em uma organização hierárquica na qual os sábios governam, os guerreiros protegem a cidade e os produtores a provêm materialmente, segundo suas inclinações e aptidões naturais, mantendo-se, dessa forma, o projeto coletivista. Essa estrutura política hierarquizada foi classificada por Popper como "comunismo de castas" e teria como escopo principal deter as mudanças sociais (POPPER, 1987, p. 62-63). Além de Popper, outros autores da tradição liberal também apresentaram críticas à filosofia política de Platão, como Ayn Rand e, até mesmo, Hannah Arendt, identificada como pensadora republicana.

Ao exilar-se na Nova Zelândia, onde foi lecionar na Canterbury University College, Popper escreveu "A Sociedade Aberta e seus Inimigos" (Open Society and its Enemies), sua obra seminal de filosofia política. Nela, sob o impacto da Segunda Guerra Mundial e com receio de que a liberdade fosse suprimida no Ocidente, especialmente pelos regimes totalitários, tentou demonstrar que uma espécie de fio condutor histórico interligava o Estado ideal platônico descrito em "A República" (e, claramente, inspirado em Esparta) aos regimes do Leste Europeu. Assim, no cerne de suas teses, Popper contrapôs a esse fio condutor fundado no coletivismo totalitário uma corrente que se teria iniciado na Atenas de Péricles com a chamada Grande Geração, cuja figura central era Sócrates, e que tinha por fundamento filosófico-político o exercício da liberdade crítica individual como meio de aprimorar as instituições democráticas. (POPPER, 1977, p. 123).

Na concepção popperiana, a corrente democrática - fundada no individualismo igualitarista e no exercício da liberdade crítica - vincula-se à herança política liberal, notadamente, Immanuel Kant e Schopenhauer, e promove um ataque ao programa filosófico-político platônico. Acusa-o de totalitário e anti-humanitário ao conceber em "A 
República" um modelo ideal de Estado cristalizador do privilégio de classe, contemplador do elitismo, da injustiça e violador do ideal de liberdade. Essa visão epistemológica classista, estática e de nítido viés totalitário se contrapõe à concepção de sociedade aberta, cujo conteúdo é, indiscutivelmente, institucionalista.

No debate acadêmico, permanece inconclusiva a discussão sobre a natureza do legado político deixado por Platão. No entanto, a pesquisa acolhe os argumentos de Karl Popper, para quem o pensamento platônico exibe indiscutíveis elementos autoritários, a ponto de influenciar decisivamente uma tradição coletivista que se contrapõe ao individualismo democrático, pedra de toque das democracias representativas do tipo liberal.

Com o advento dos chamados regimes híbridos ou iliberais, após o fim da Guerra Fria, os aspectos normativos das críticas liberais endereçadas à tradição influenciada pelo pensamento político de Platão passaram a ocupar um lugar de maior visibilidade no debate acadêmico. É nesse contexto que o trabalho, por intermédio de pesquisa bibliográfica de abordagem qualitativa, propõe-se a discutir e revisitar a literatura para atualizar o debate sobre o legado do coletivismo platônico, sob o olhar liberal de Karl Popper, e a sua influência no advento de regimes híbridos (democrático-autoritários).

Para o desenvolvimento dessas ideias, o trabalho se divide em 3 capítulos. O primeiro capítulo centra-se na exposição da alegoria da caverna (Livro VII da obra "A República") e de seus simbolismos à organização política, social e educacional da cidade grega, fundamentalmente aqueles que serão usados por Popper em sua análise crítica à teoria platônica; no capítulo seguinte, são apresentadas as principais reflexões críticas que o filósofo-político liberal Karl Popper faz ao modelo totalitário de Platão presentes em "A Sociedade Aberta e seus Inimigos”, em uma clara tentativa de desmistificar a carga humanitária e idealista que a obra do filósofo grego transmitiu como importante legado para a cultura ocidental; e, por fim, o último capítulo analisa como o advento dos chamados regimes híbridos (democrático-autocráticos) desvela a permanência do pensamento político platônico.

\section{AS PRINCIPAIS DIRETRIZES DO PENSAMENTO DE PLATÃO: UM PRO- JETO AUTORITÁRIO?}

No Livro VII da obra "A República", Platão utiliza-se de diálogos entre dois personagens, Glauco e Sócrates, para apresentar um modelo ideal de cidade (PLATÃO, 2000, p. 319-357). No diálogo, Sócrates sugere a Glauco que imaginasse certa experiência em que homens, vivendo desde a infância em uma habitação subterrânea em forma de caverna, com uma pequena entrada aberta para a luz, encontram-se algemados nas pernas e nos pescoços, de tal maneira que só lhes é dado permanecer no mesmo lugar e olhando para frente. Esses homens, aprisionados na obscuridade quase completa da caverna, vivem sem nunca ter visto o mundo exterior nem a luz do Sol, mas apenas as sombras dos objetos, dos outros homens e de si próprios. Nessas condições, não pensavam que a realidade fosse outra senão a sombra dos objetos que viam. 
Indaga-se a Sócrates o que aconteceria com esses homens se alguns deles fossem libertados desse obscurantismo ilusório. Responde Sócrates afirmando que, após um árduo caminho de obstáculos até a saída da caverna, sentir-se-iam divididos entre a incredulidade e o deslumbramento, e o primeiro impulso deles seria o de retornar à caverna em busca do breu acolhedor e familiar da escuridão (PLATÃO, 2000, p. 20).

Sentindo-se sem disposição para regressar à caverna, em virtude da rudeza do caminho, o prisioneiro, aos poucos, habitua-se ao mundo exterior e à luz do Sol. Doravante, lutará para que os outros prisioneiros também abandonem a caverna sombria em busca da luminosidade do mundo exterior. Ocorre que, ao regressar à caverna subterrânea, os demais prisioneiros não creriam no novo mundo apresentado pelo companheiro outrora encarcerado e, diante da insistência em afirmar a existência de um outro mundo exterior, os prisioneiros matá-lo-iam, uma vez que, em suas concepções, o liberto, ao ter subido ao mundo superior, estragara a sua visão.

Ao conceber essa experiência em uma caverna subterrânea, Platão apresenta, de forma alegórica, o mundo das aparências sensíveis (sombras projetadas na caverna), os preconceitos e as opiniões (grilhões), a verdade e o bem (Sol), o mundo inteligível (mundo iluminado pelo sol da verdade) e a filosofia (instrumento capaz de libertar os prisioneiros da obscuridade das ilusões).

Com essas ideias, o filósofo grego concebe um modelo de cidade justa governada por filósofos, que deveriam receber uma formação adequada (educação ideal aos governantes de um Estado ideal comandada pelas próprias instituições estatais) a fim de assumir o comando do Estado. As mães e as babás seriam, por exemplo, orientadas a colaborar na criação de "belos mitos" junto às crianças, reforçando, assim, a força do credo político estacionário, voltado para deter as mudanças sociais - viés totalitário concebido por Platão. Nas palavras de Platão:

Em primeiro lugar, então, devemos manter vigilância sobre os que criam os mitos e, se criarem um belo mito, deveremos incluí-lo em nossa seleção e, se não, excluí-lo. Os mitos que forem escolhidos nós persuadiremos as amas e as mães que os narrem às crianças e com elas moldem as almas delas muito mais que com suas mãos lhes moldam os corpos. Muitos dos mitos que elas hoje narram às crianças devem ser jogados fora. [...] Os que Hesíodo e Homero contavam, falei, e também outros poetas. Foram eles que compuseram esses mitos mentirosos e os narravam e narram ainda aos homens (PLATÃO, 2000, p. 75).

Referida formação inclui o conhecimento da matemática, da geometria, da estereometria, da astronomia e da dialética como condição indispensável para se chegar à verdade pura do mundo inteligível e do pensamento filosófico, em oposição às sombras opacas da ignorância (unidade da verdade x multiplicidade das opiniões).

Após seguir o percurso desse longo processo formativo-educacional (técnica libertadora do espírito, arte de fazer a conversão da ignorância para a luz), o filósofo, liberto da obscuridade do mundo sensível, passa a viver sob a luminosidade, a clareza e a distinção do mundo 
inteligível, e é aí que se inicia a sua missão política de ter de conduzir os demais indivíduos, ainda presos aos grilhões da ignorância, à luz e à verdade libertadora proporcionada pelo conhecimento da essência das coisas e pela ascensão da alma para a região do inteligível (ideia do bem). Trata-se do movimento dialético ascendente (do mundo sensível ao mundo inteligível) e descendente (após a ascensão, consiste no retorno do filósofo ao mundo sensível para conduzir os demais indivíduos ao conhecimento da ideia do bem).

Com a idealização desse modelo, a pólis grega deveria assumir uma estrutura tripartite, formada por três classes sociais: 1) a classe dos governantes (filósofos); 2) a classe dos artesãos e dos comerciantes (garantia de sobrevivência material da cidade); 3) e a classe dos guerreiros (defesa da cidade). A cidade justa seria exatamente aquela governada pelos sábios, protegida pelos guerreiros e mantida materialmente pelos artesãos e pelos comerciantes. Cada classe, formada de acordo com suas aptidões naturais (seleção a partir das inclinações), deverá cumprir sua função para a harmonia da cidade, que deve ser racionalmente conduzida pelos filósofos - únicos capazes de pensar no bem comum da pólis e governá-la com justiça (PLATÃO, 2000).

Nota-se a proposição de um modelo ideal de cidade justa a partir da construção de um programa político que tenha como objetivo a realização da justiça e do bem comum associada a uma educação necessária à libertação do espírito e ao conhecimento da ideia do bem e de uma estrutura tripartite de classes sociais organizadas na virtude militar da disciplina, com base nas inclinações e nas aptidões dos cidadãos.

No que se refere à organização política da cidade ideal, Platão (2000) imagina um poder político centrado em um Governo de Filósofos. Nesse sentido, apenas os homens dotados de razão, conhecedores das ciências, são os que, de fato, devem guiar os demais homens e conduzir os rumos da coisa pública. À luz da sua teoria, homens aprisionados no mundo sensível são incapazes de guiar homens tão aprisionados como eles próprios. Homens sábios (filósofos), ao contrário, conhecedores da ideia do bem, são os únicos capazes de conduzir os demais homens à libertação dos grilhões que os impedem de ascender ao mundo inteligível das ideias.

Partindo desse pensamento, Platão (2000) concebe um modelo de educação - paidéia filosófica - dos governantes da cidade ideal como forma de permitir, gradativamente, que os indivíduos alcancem os estágios diferenciados da libertação (passagem de um grau de conhecimento para outro) por meio de um ato de conversão do espírito que perpassa por sucessivas etapas do conhecimento: conhecimento sensível, conhecimento pela crença (opinião), conhecimento científico (conhecimento dos números, das causas, das leis) e conhecimento metafísico (das ideias, do bem), com o indispensável auxílio do governante-sábio (filósofo).

Registre-se que a ideia de Paidéia, concebida inicialmente como uma teoria destinada a cuidar da educação infantil, surgiu em Atenas e, no século IV a.C, passou a abranger a relação do indivíduo com os demais cidadãos, tornando-o capaz de participar ativamente da vida da pólis, sobretudo dos debates na Ágora, lócus essencial da democracia ateniense, que 
teve em Péricles o seu grande líder e tribuno, como se pode constatar, por exemplo, pelo relato de Tucídides na obra clássica História da Guerra do Peloponeso. Aqui, os contrastes entre as concepções de Sócrates e de Platão são significativos e igualmente realçados por Popper em Open Society.

Embora tenha sido discípulo de Sócrates, Platão concebeu uma educação rígida e hierarquizada, de clara inspiração no modelo espartano, segundo entendeu Popper (1998, p. 69). Bem diferente era a visão de Sócrates no tocante à educação da juventude e à formação dos cidadãos, pois acreditava que todos podiam ter acesso ao conhecimento, não se excluindo disso nem mesmo os escravos de Atenas. Popper não lhe poupou elogios, vendo-o como um dos defensores da nascente sociedade aberta:

Já mencionei alguns aspectos do ensinamento de Sócrates: seu intelectualismo, isto é, sua teoria igualitária da razão humana como meio universal de comunicação; sua insistência na honestidade intelectual e na autocrítica; sua teoria igualitária da justiça e sua doutrina de que é melhor sofrer a injustiça do que infringi-la a outros. Penso que esta última doutrina é a que melhor nos ajuda a compreender o âmago de seu ensinamento, seu credo individualista, sua crença no indivíduo humano como um fim em si mesmo (POPPER, 1998, p. 205).

Diversamente, Platão (2000) apresenta-se como um crítico à ideia de democracia. Para ele, existem requisitos indispensáveis para a realização de um bom governo, a saber: ausência de ânsia pelo poder, conhecimento do bem (mundo inteligível), agudeza de espírito para o estudo, ausência de dificuldade em aprender, preocupação com a memória, força e gosto pelo trabalho em todas as suas formas. Com isso, Platão (2000) defende o privilégio de classe e rechaça a lógica democrática pautada no igual direito de todos (sábios ou não) em participar do governo da pólis, uma vez que cidadãos sem acesso à ideia do bem, prisioneiros, portanto, das trevas que os conduzem às simples aparências sensíveis, são incapazes de, no breu das ilusões, ascender ao brilho e à luminosidade dos raios do Sol.

Popper (1987), no entanto, como será visto na próxima seção, promove um pesado ataque ao programa filosófico-político platônico e acusa-o de totalitário e anti-humanitário ao conceber em "A República" um modelo ideal de Estado cristalizador do privilégio de classe, contemplador do elitismo, da injustiça e violador do ideal de liberdade. Essa visão epistemológica classista, estática e, portanto, de nítido viés totalitário contrapõe-se à concepção de sociedade aberta popperiana cujo conteúdo é, indiscutivelmente, institucionalista.

\section{AS CRÍTICAS LIBERAIS DE KARL POPPER AO PROGRAMA POLÍTICO DE PLATÃO}

Karl Popper, ferrenho crítico das doutrinas políticas totalitárias, dedica uma de suas obras aos inimigos das sociedades abertas e democráticas. Critica-os ao relativizarem a liberdade em prol de um suposto bem comum (ideal coletivista). Popper centra suas reflexões no pensamento de Platão e acusa-o de totalitário, anti-humanitário e elitista. Popper recua, portanto, à antiguidade grega para demarcar uma cisão inconciliável entre a trajetória dos 
defensores da sociedade fechada - inaugurada por Platão e estendida à contemporaneidade tanto por autores de esquerda quanto de direita - e os adeptos da sociedade aberta - iniciada por Sócrates até alcançar a democracia liberal do tempo presente. É curioso notar como Popper, embora tenha rechaçado o chamado historicismo platônico (pelo qual a história caminharia em um único sentido), concebe uma teoria do fio condutor histórico ao prescrever o embate secular entre as forças da sociedade detida e da sociedade aberta.

O regime social de classes idealizado por Platão, baseado em uma estrita divisão hierárquica e segmentária da sociedade, associado à ideia de identificação do destino do Estado com o da classe dirigente (governo de uma só classe, dos filósofos) que impõe regras rígidas para criar e educar os demais segmentos da sociedade, com estrita supervisão (censura das atividades intelectuais e propaganda contínua das classes dirigentes visando à unificação do pensamento) e coletivização dos interesses de seus membros são ideias tachadas por Popper de totalitárias, antidemocráticas e avessas à liberdade dos cidadãos (POPPER, 1987, p. 100).

Segundo Popper (1987), o programa político de Platão, longe de ser superiormente moral, identifica-se fundamentalmente com o totalitarismo. Assim, mesmo considerando que, à primeira vista, suas ideias sejam interpretadas como detentoras de uma elevada carga idealizada de moralidade, a dizer pelas ideias morais de bem, justiça, verdade, sabedoria e felicidade, reconhece Popper que essas interpretações desconsideram as inclinações reacionárias e o nítido teor anti-igualitário da sua teoria política.

Platão (2000), ao abordar sobre o tema justiça, defende a ideia de que qualquer mudança ou mescla no interior das três classes deve ser compreendida como injusta. Seu alvo fundamental era deter a mudança política. Ao defender o predomínio e o privilégio de classe, sustenta que o Estado é justo quando o governante governa, o trabalhador trabalha e o escravo se deixa escravizar. Segundo Popper, (1987) esse ponto de vista de Platão é incompatível com o que costumeiramente se considera como justo - a ausência de semelhantes privilégios e a igualdade no tratamento dos indivíduos. Nesse sentido, por detrás da definição de justiça de Platão, situa-se, fundamentalmente, sua exigência do predomínio totalitário de uma classe sobre a outra, o que, para Popper, trata-se da consagração da mais absoluta injustiça (POPPER, 1987, p. 104-105).

Receoso de que poderia estar sendo injusto e a-histórico com as ideias de Platão ao esperar uma antecipação da moderna ideia de justiça como igualdade dos cidadãos perante a lei (em oposição à ideia de justiça em um sentido holístico - justiça da totalidade do Estado), Popper (1987) investigou o uso grego do termo justiça, a fim de evitar problemas metodológicos em sua análise, e concluiu que o modo como os gregos empregavam a palavra justiça era semelhante ao emprego individualista e igualitário do termo, o que ratificou as críticas de Popper ao filósofo grego.

Popper apresenta os princípios mais importantes do movimento humanitarista, a saber: a) princípio igualitário: eliminação dos privilégios naturais e da parcialidade no trato dos cidadãos. Tal princípio não ignora as justas recompensas pelo merecimento; b) individua- 
lismo: o individualismo não é incompatível com o altruísmo; c) liberdade: deve ser tarefa do Estado proteger a liberdade dos cidadãos. Popper contrapõe-os às ideias diametralmente opostas apresentadas por Platão, quais sejam: a) princípio do privilégio natural; b) princípio do holismo ou coletivismo: ideia segundo a qual os indivíduos deveriam se submeter aos interesses do todo, uma vez que eles são nitidamente inferiores se comparados à totalidade do Estado. Isso vai ao encontro da compreensão de unidade e estabilidade do todo coletivo; c) princípio de que deve ser tarefa e objetivo do indivíduo manter e reforçar a estabilidade do Estado (POPPER, 1987, p. 109-129).

Tal divergência teórica entre a ética humanitária (interpretação individualista e igualitária da justiça) e as ideias de Platão leva Popper à conclusão de que o código moral de Platão, a despeito das equivocadas interpretações de sua teoria que afirmam o caráter humano, altruísta e cristão (cristianismo antes de Cristo) das suas análises, é estritamente totalitário, anti-igualitário e anti-individualista.

Popper (1987) aponta também o nítido viés utilitário da teoria de Platão, ao defender o interesse do Estado como critério de moralidade. A utilidade coletiva, a pretexto de gerar a satisfação do ente coletivo, viola, frontalmente, os direitos dos indivíduos (o interesse do Estado acaba por dominar a vida dos cidadãos). As razões de Estado não podem ter como diretriz apenas a otimização do bem-estar geral, sem considerar outras dimensões de moralidade, justiça e equidade. Trata-se de uma moralidade calculada a partir dos benefícios e das consequências de um ato ou ação (egoísmo coletivo). Não apresenta em si um valor intrínseco, mas avalia a utilidade das ações à satisfação coletiva, autorizando o sacrifício de uns em nome do maior bem-estar geral possível da comunidade. Segundo Popper, o utilitarismo platônico é incompatível com a ética humanitária.

Platão (2000) via o problema fundamental da política na indagação: quem deverá dirigir o Estado? De acordo com Popper (1987), a indagação, por si só, estava equivocada porque reduzia a questão central política ao apontar ou selecionar qual classe social deveria governar, atribuindo-se, então, à classe social eleita um poder político essencialmente livre de controles institucionais, em que os indivíduos os quais o assumem poderiam, quase inteiramente, fazer o que lhes apraz (poder ilimitado, incontrolado).

Essa ausência de accountability ${ }^{1}$ conduz, quase que inevitavelmente, a inserção no discurso político da preocupação do perfil adequado para o bom governante, tal como Platão apresentou em "A República", ao defender que os filósofos, após um adestramento para o exercício da liderança, são os que melhores condições possuem para assumir o comando político do Estado, em virtude do acesso privilegiado ao mundo inteligível das formas e das ideias, indispensável à fundação de uma cidade virtuosa, construída à luz da bondade e da sabedoria, e à necessária libertação dos espíritos aprisionados nas aparências sensíveis.

Segundo Popper (1987), o melhor encaminhamento para a questão seria substituí-la pela pergunta: como poderemos organizar as instituições políticas de modo tal que maus ou incompetentes governantes sejam impedidos de causar demasiado dano? Popper aponta os 
perigos do viés personalista do Filósofo-Rei e defende que os controles institucionais são de suma importância para o exercício do poder político (o interesse é desviado das questões essencialmente pessoais para as institucionais), razão pela qual a preocupação exagerada em delimitar o perfil ideal de governante se torna desprovida de importância, devendo ser substituída pela inserção de controles adequados no interior das instituições do Estado controles institucionais dos governantes pelos governados.

Popper (1987) aponta as influências de Sócrates no pensamento de Platão, especialmente, no que se refere ao seu intelectualismo moral, segundo o qual há uma clara identificação entre a bondade e a sabedoria (a falta de conhecimento é responsável por todos os enganos morais); e a ideia de que excelência moral pode ser ensinada, prescindindo-se de quaisquer faculdades morais particulares, a não ser a universal inteligência humana.

Para Popper (1987), as exigências de Sócrates relativas ao seu intelectualismo foram utilizadas de maneira distinta no discurso de Platão. Sustenta Popper que o intelectualismo de Sócrates era fundamentalmente igualitário e individualista e o de Platão, ao contrário, nitidamente totalitário. Isso porque o alvo educacional de Platão não era o despertar da autocrítica, como propusera Sócrates, ao defender a ideia igualitária e libertária de que existe um elo intelectual mútuo entre os homens, um meio de compreensão universal realizado por intermédio da razão.

Para Popper, o filósofo de Sócrates é um indivíduo racional e modesto. Para Platão, que defendia a exigência de um monopólio educacional da classe dirigente (educação como departamento do Estado), acrescido da mais estrita censura até mesmo dos debates orais, ao contrário, o filósofo (Filósofo-Rei) era um semideus (não o devoto perseguidor da sabedoria, mas seu orgulhoso possuidor), único capaz de pôr fim aos males da vida social, à agitação do mal nos Estados e à instabilidade política dos governos das cidades gregas (POPPER, 1987, p. 143-167).

O modelo de seleção institucional da classe dirigente (tarefa do Estado de escolher os mais hábeis intelectualmente - os filósofos) proposto por Platão, atende, segundo Popper, aos fins propostos pelo filósofo grego de deter toda mudança política, limitar a iniciativa, a originalidade, a liberdade individual, bem como assinalar os governantes e erguer uma barreira bem clara entre governantes e governados (educação filosófica de Platão idealizada a partir de uma função política definida, qual seja, estabelecer uma classe política dominante permanente). Com tal modelo, objetivava Platão preservar o status quo político pelo controle institucional da sucessão na liderança. O controle deveria ser, fundamentalmente, educacional, baseado em uma concepção autoritária do ensino. Segundo Popper (1987, p. 152), "a exigência impossível de uma seleção institucional de líderes intelectuais põe em perigo a própria vida não só da ciência, como da própria inteligência."

O pensamento político de Platão, mais voltado às formas ideais, foi alvo de ataque e objeção de outros pensadores vinculados à tradição aristotélica, quer se encontrem dentro quer se encontrem fora do liberalismo (liberalismo nos mais variados espectros). Arendt $(1989,2010)$ critica a rigidez com que Platão idealiza a pólis, de modo a impedir a ocorrência de um dos elementos constitutivos essenciais para a vida política - a imprevisibilidade da 
ação (ECCEL, 2012, p. 32). Essa hierarquização institucional de Platão eliminaria, assim, a possibilidade de que o novo ocorresse, sufocando a liberdade política. Há, aqui, uma similaridade ou aproximação com o pensamento de Popper, que, como foi aduzido, via na rigorosa estratificação platônica um bloqueio irremediável às mudanças sociais, bem como uma utopia disruptiva de uma ideologia totalitária. Em contrapartida, no plano epistemológico, Ayn Rand rejeita a teoria das formas concebida por Platão, segundo a qual haveria um mundo invisível aos olhos humanos. Rand defendeu que a realidade pode ser percebida ou apreendida pelos sentidos e correlacionada, de forma objetiva e não contraditória, com o conhecimento acumulado por cada ser humano.

Nesse passo, somente a economia de livre mercado poderia conceder o necessário espaço para que a liberdade florescesse, permitindo a cada pessoa decidir o que fazer - por meio do exercício lógico não contraditório - sem a interferência invasiva de burocracias estatais pretensamente iluminadas (RAND, 2018, p. 1-18). A concepção teórica do autor colide, assim, com a ideia central do platonismo que reclama a necessidade da constituição do Rei Filósofo à frente de desenhos político-institucionais rígidos e/ou de pouca flexibilidade, sobretudo no que concerne à alternância de grupos políticos no poder por meio de eleições livres, justas e universais. Cumpre anotar que, para Alejandro Mercado, há uma semelhança entre a filosofia política de Ayn Rand e Karl Popper no que concerne ao rechaço das utopias coletivistas: "El liberalismo, por su parte, no es, para Rand, un catecismo, no tiene una agenda para el futuro, no tiene una utopia de felicidad, pues considera, como Karl Popper, que todo intento de crear un paraiso termina en el infierno" (MERCADO, 2007, p. 199-200).

Provavelmente por não ter realizado suas promessas mais caras, por exemplo, promover maior igualdade social entre as pessoas, o liberalismo sofre hodiernamente forte contestação pública ao redor do planeta, inclusive nos países economicamente mais avançados. Decerto, tal situação fática concorreu para o advento dos chamados regimes híbridos cujos desenhos político-institucionais exibem claros traços distintivos da permanência do pensamento platônico coletivista.

\section{O ADVENTO DE REGIMES HÍBRIDOS E O LEGADO PLATÔNICO}

Para contextualizar a discussão em torno do advento de regimes políticos híbridos, cabe indagar se Popper foi injusto com Platão ou se tentou caricaturar sua concepção de Estado Perfeito, como foi algumas vezes acusado. No livro "A República de Platão", há evidências claras de que a análise de Popper é correta. $O$ trabalho acolhe, portanto, os argumentos de Karl Popper que acenam à identificação do pensamento platônico a elementos autoritários. O projeto político de Platão descrito em "A República” pode ser classificado como holístico ou totalizante, pois concebe o controle rígido dos governados, do berço ao túmulo. Na verdade, "A República” fornece um formidável arsenal de instrumentos para o estabelecimento de regimes totalitários ou de suas versões atenuadas, como o regime democrático-autoritário. 
Tome-se, por exemplo, a educação como uma das referências temáticas entre muitas contidas no livro "A República”. Platão concebia como parte integrante do processo educacional a manipulação dos mitos com a exclusão daqueles ensinados por Hesíodo e Homero. Essa educação, que pressupunha o estabelecimento dos mitos escolhidos pelo Estado e que ia do berço ao túmulo, foi adotada pelos movimentos totalitários, à esquerda e à direita, durante o conflituoso século XX. Para esses regimes, não bastava o controle dos corpos. Controlavam-se, sobretudo, as mentes dos cidadãos convertidos em súditos e, não raro, rebaixados à condição de vassalos ou mesmo escravos - no século XX, o genocídio de alguns povos considerados como "racialmente inferiores" converteu-se em política de Estado, como sucedeu no caso do nazismo.

Popper (mas não somente ele) associou Esparta e o Estado Ideal de Platão aos regimes totalitários do século XX, já Atenas, com sua liberdade política e exercício efetivo do comércio marítimo, foi por ele identificada como a gênese originária da sociedade aberta, hodiernamente representada pelas democracias representativas do Ocidente.

Também aqui cabe indagar se Karl Popper exorbitou na formulação teórica acima feita, sobretudo na associação que fez entre Esparta - "comunismo da casta dirigente" - com os regimes comunistas do Leste Europeu (ou socialismos realmente existentes - sorex, a designação semântica importa menos do que o fato evidente de que ruíram espetacularmente), chamando a ambos de sociedades fechadas e apontando Platão como seu primeiro idealizador. Do mesmo modo que antes, pode-se dizer que a associação popperiana não parece ter sido despropositada porquanto Platão e seu Estado Ideal foram corriqueiramente identificados como a primeira matriz do ideal comunista, conforme entendimento de Giuseppe Bedeschi, para quem "costuma-se fazer remontar a Platão a primeira formulação orgânica de um ideal político comunista” (BEDESCHI, 1983, p. 204).

No entanto, nem todos os intelectuais consideraram Platão como um manifesto inimigo da democracia. Para Ernst Cassirer, por exemplo, Platão foi, antes, um pensador que possuía "um espírito inteiramente aberto" e não tinha Esparta como seu ideal político. Segundo ele, há uma só situação que Platão rejeita e condena absolutamente: "a alma tirânica e o estado tirânico" Platão "insiste sobre os defeitos da democracia ateniense; mas, por outro lado, não aceita o Estado lacedemônio como seu verdadeiro modelo. $O$ modelo que ele procura está muito além desse mundo empírico e histórico" (CASSIRER, 2007, p. 22).

A outra tradição, inaugurada por Sócrates e seus sucessores, enfatizou a liberdade de crítica e de consciência, assim como buscou promover não a igualdade plena, mas a igualdade de oportunidades para aqueles que, por meio da educação e do estabelecimento de mecanismos de controle popular sobre os governantes, desejassem construir instituições sólidas e, é claro, permitir a ascensão social de todo e qualquer cidadão. Nesse aspecto, Sólon, ao criar leis iguais para pobres e ricos, lançou as bases rudimentares do que ele mesmo chamou de justiça equitativa; por seu turno, Sócrates acreditava que até mesmo os escravos poderiam, mediante uma educação adequada, compreender os intrincados problemas abstratos discutidos pelos filósofos gregos. 
Os contrastes entre as duas tradições são, pois, abissais e espraiaram o seu legado até os dias atuais. Nesse passo, defende-se o pensamento esposado por Popper que se apoia na crítica à herança platônica, que, como vimos, pretendia estabelecer um Estado Ideal com rígida hierarquia social, inaugurando uma tradição completamente contraposta à ideia popperiana de uma sociedade aberta às mudanças sociais contínuas porque está sujeita à crítica e à reforma gradual das instituições democráticas.

Note-se que nem todas as utopias foram benevolentes com o gênero humano, razão pela qual Leo Strauss, por exemplo, considerou o livro "A Utopia”, de Thomas More, uma imitação da utopia platônica, ainda que fosse menos austera do que sua matriz grega, pois, segundo ele, "I have in mind Sir Thomas More. His Utopia is a free imitation of Plato's Republic. More's perfect commonwealth is much less austere than Plato's" (STRAUSS, 2008, p. 61).

Uma breve leitura sobre a realidade política mundial do tempo presente indica que persistem crenças políticas que alimentam concepções de filosofia política segundo as quais as liberdades individuais podem e devem ser sacrificadas em nome da construção da felicidade coletiva. Há uma literatura consistente em Ciência Política que trata do advento dos chamados regimes híbridos ou iliberais que mesclam simultaneamente traços democráticos e autoritários cujo escopo é se contrapor às democracias representativas do tipo liberal.

A compreensão dos regimes híbridos importa para a discussão porque demonstra a permanência do pensamento político platônico em muitas dimensões do momento presente. Inicialmente, cumpre conceituar regime híbrido, pois se trata de um termo polissêmico, capaz de causar, não raro, certa confusão pelo seu uso abusivo e/ou inadequado. Em síntese, Corrales e Hidalgo (2013, p. 49) definem regime híbrido como "un régimen en el que coexisten rasgos democráticos y autocráticos simultaneamente, y en el que las reglas de juego son arbitrariamente utilizadas en desmedro de la oposición." Sem embargo, embora mantenham em funcionamento o sistema de competição eleitoral, não é raro que os regimes híbridos alterem as regras do jogo para criar obstáculos ou constrangimentos legais para a atuação da oposição com o objetivo de favorecer as candidaturas oficialistas. Não raro, países que realizam oficialmente eleições acabam não sendo considerados efetivamente democráticos ou ao menos, considerados como democracias formais ou de baixa intensidade. ${ }^{2}$

Após a queda do Muro de Berlim, as democracias liberais do Ocidente despontaram como vitoriosas dos conflitos decorrentes da Guerra Fria. A combinação de economia de mercado com democracia representativa do tipo liberal parecia, então, ter sido convalidada pela experiência histórica como o modelo capaz de engendrar crescimento econômico e liberdade política infindáveis. Houve uma onda de redemocratização e ditaduras militares foram, gradual e pacificamente, substituídas por democracias nas quais ocorriam competições eleitorais legítimas.

Ocorre, todavia, que, pouco tempo depois, um novo - e surpreendente - fenômeno surgiu no horizonte político-institucional, colocando em dúvida o frágil consenso em torno do suposto triunfo definitivo das democracias liberais em face dos regimes coletivistas do 
período da Guerra Fria. Tratava-se do advento das chamadas democracias iliberais, fenômeno político que ocorreu na América Latina, na Ásia e na chamada Eurásia, notadamente em países que haviam pertencido ao mundo comunista. No artigo icônico The Rise of Illiberal Democracy, publicado na Foreign Affair em 1997, Fareed Zakaria advertiu para o fato de que as emergentes democracias iliberais apostavam nas formas plebiscitárias de governo, mesmo que em detrimento de valores, liberdades e direitos individuais. Esse desenho institucional se contrapõe à tradição ocidental assentada no constitucionalismo liberal.

Como a contrariar a crença hiperbólica e, portanto, equivocada de que a história caminhava em um único sentido - o sentido que apontava para o triunfo do liberalismo como estágio final da evolução histórica -, extensa literatura surgiu, na esteira da contribuição de Zakaria, para examinar a natureza das democracias iliberais, agora chamadas de regimes híbridos.

Nesse passo, vale conhecer os trabalhos de Corrales e Hidalgo (2013) (El Régimen Híbrido de Hugo Chávez en transición (2009-2013); Corrales (2011) (A Setback for Chávez); Levine (2002) (The Decline and Fall of Democracy in Venezuela: Ten Theses); Levine e Molina (2012) (Calidad de la Democracia en Venezuela); Kornblit (2013) (Chavismo after Chávez?); Urribarrí (2016) (Venezuela (2015): un régimen híbrido in crisis); Gamboa (2016) (Venezuela Aprofundamento do autoritarismo ou transição para a democracia?). De qualquer modo, deve ser salientado que os regimes híbridos podem surgir à direita (o fujimorismo no Peru) ou à esquerda (o chavismo na Venezuela), convergindo ambos em seus propósitos de construir instituições de natureza iliberal.

As ideias centrais que justificam a implantação e a vigência dos regimes híbridos guardam evidente conexão com o pensamento político de Platão, desvelando, assim, a permanência do seu ideal coletivista. Os arranjos institucionais dos regimes híbridos caracterizam-se por um exercício de poder com traços autoritários que conduzem o povo rumo a um tipo ideal de sociedade, desiderato que remete ao projeto coletivista de Platão. De certo modo, essa característica marcante dos regimes híbridos favorece o desenvolvimento de democracias iliberais, propiciando um desamparo à proteção aos direitos e liberdades individuais, à separação dos poderes, aos limites ao poder do Estado e ao individualismo ético.

Nesse sentido, a ideia de que os indivíduos com suas preferências importam perde relevância nos arranjos institucionais dos regimes híbridos. Assim, Ellner (2012, p. 110-115) classifica, por exemplo, certos regimes de "democracia social radical", que se encontram em oposição à democracia liberal e reconhece que os velhos controles desenhados para evitar o abuso de poder acabam sendo minimizados em nome do governo das maiorias, assim como o uso desmedido do poder acaba por violar a separação de poderes, um dos pilares da democracia liberal.

De qualquer modo, a ascensão dos regimes híbridos ao redor do globo sugere a permanência hodierna de resquícios do pensamento político platônico nos aspectos anteriormente apontados, de modo a manter a discussão em aberto no campo acadêmico, bem como incrementando o clash of ideas também no campo estritamente político. 


\section{CONCLUSÃO}

Platão (2000), no Livro VII da obra "A República", apresenta um modelo ideal de cidade justa construída, fundamentalmente, sobre os pilares de um programa político fundado na realização da justiça e do bem comum; na ideia de identificação do destino do Estado com o da classe dirigente; em uma paidéia filosófica necessária à libertação do espírito e ao conhecimento da ideia do bem; na imposição de rígidas regras para criar e educar a sociedade; em uma estrutura hierarquizada tripartite de classes sociais organizadas com base nas inclinações e nas aptidões dos cidadãos; na coletivização dos interesses dos cidadãos em detrimento de um modelo de justiça humanitário e individualista. Não obstante a importância das ideias de Platão para a filosofia ocidental, Karl Popper acusa-as de serem, essencialmente, enraizadas em preconceitos que desconsideram as inclinações reacionárias e o nítido teor anti-igualitário, totalitário, antidemocrático e elitista de sua teoria política.

Contrariamente a Platão, Popper defende a consagração do princípio igualitário com a eliminação dos privilégios naturais e da parcialidade no trato dos cidadãos; do individualismo; da liberdade e das instituições da democracia representativa, contra totalitarismos de qualquer tipo, seja de direita, seja de esquerda. Esses valores, fundamentados na ideia de humanismo ético, são, à luz da interpretação popperiana, inteiramente negados na obra de Platão. Nesse sentido, Popper acusa Platão de ser sensivelmente hostil ao credo humanitário. Acusa-o, igualmente, de utilitário, ao defender a utilidade coletiva do Estado como critério de moralidade por excelência para nortear as diretrizes políticas, mesmo que em detrimento de uma justiça individual.

Nesse sentido, Popper apresenta-se como um ferrenho crítico ao governo dos filósofos proposto por Platão. Segundo ele, tal modelo provoca um imobilismo político, a legitimação do status quo e uma sensível limitação à liberdade individual. Desse modo, por trás da soberania do Rei-Filósofo, oculta-se a aspiração de um projeto de poder totalitário, reacionário, elitista e anti-humanitário de uma sociedade fechada à liberdade, à criatividade, à originalidade e à exaltação de uma justiça pautada na valorização do indivíduo e de sua humanidade.

Assim, sugere a substituição da proposição platônica (2000) acerca de quem deve governar pela ideia de Popper (1987) segundo a qual questiona como as instituições devem organizar-se para que maus e incompetentes governantes sejam impedidos de causar demasiado dano. A amplitude dessa nova forma de colocar a questão se contrapõe, nitidamente, à teoria da soberania platônica, especialmente ao desviar o foco do falso problema de saber que classe social deve governar e redirecioná-la para as questões e problemas de natureza eminentemente institucional, sobretudo o exercício do instituto largamente utilizado da accountability.

Além de Popper, parte considerável da literatura em diversos campos do conhecimento aponta a existência de traços autoritários no pensamento político de Platão, notadamente pelas proposições contidas em "A República". A tradição liberal, mais voltada para a defesa do indivíduo em face do agigantamento dos poderes estatais, trata com desconfiança e, não raro, com aberta rejeição os arranjos institucionais propostos por Platão. 
Considera-se que Popper tenha realizado provavelmente o mais pesado ataque ao pensamento político de Platão. A literatura em Teoria Política discute se Popper foi justo ao fazer uma crítica tão incisiva do pensamento político de Platão. Entende-se que a análise conjuntural e prescritiva do pensamento platônico feita por Popper apresenta-se como correta. Essa ideia converge com a de Ian Shapiro que, apoiando-se em Miles Burnyeat, considera que a interpretação de Popper do pensamento platônico é "a mais plausível” (SHAPIRO, 2006, p. 254). Entretanto, trata-se, sem dúvida, de uma discussão acadêmica inconclusiva, sujeita a contínuas interpretações distintas.

Ao final do século XX, a queda do muro de Berlim e o colapso do império soviético constituíram-se em eventos históricos que sugeriam o triunfo do liberalismo. Todavia, a própria ideia de um historicismo liberal afigura-se equivocada, considerando que a tradição liberal não admite a inexorabilidade de um sentido (ou caminho) único para a trajetória da história. Apenas alguns anos depois do fim da Guerra Fria, mas ainda no século XX e na esteira da contribuição de Fareed Zakaria, assistiu-se ao advento das chamadas democracias iliberais. No século XXI, a literatura identificou a emergência de regimes políticos que mesclam simultaneamente traços autoritários e democráticos, sendo nominados de regimes híbridos cujos escopos se contrapõem à manutenção, à consolidação e ao aprimoramento das instituições típicas da democracia representativa do tipo liberal.

Como visto, os regimes híbridos têm a pretensão de erigir instituições voltadas à consolidação de democracias diretas ou plebiscitárias e reclamam, muito frequentemente, a condução do processo político de modo autoritário, propiciando uma burla à democracia por meios aparentemente democráticos. A ideia de um povo em constante mobilização sob uma liderança centralizada e forte, defendendo projetos coletivos permanentes mesmo que em detrimento de valores, direitos e liberdades individuais, remete ao legado platônico e desvela a permanência, nos dias atuais, de resquícios de sua concepção política holística, ainda que com as adaptações de seu tempo histórico.

A tradição liberal opõe-se claramente a essas novas formas de coletivismo, de verniz ambíguo, porque as identifica como adversárias das liberdades individuais e outras garantias constitucionais - como o direito à contestação pública, por exemplo - asseguradas pela democracia representativa. Não se trata aqui de mera especulação, uma vez que o ideário declarado dos regimes híbridos não deixa espaço para dúvida quanto ao propósito de limitar as instituições da democracia liberal.

Portanto, o argumento central da pesquisa centra-se na ideia de que o pensamento coletivista de Platão exibe uma inegável resiliência (ou permanência) na atualidade, encontrando-se algumas de suas marcas distintivas na condução dos regimes híbridos. Permanece, pois, a tensão (adaptada aos novos tempos) entre o coletivismo de recorte platônico, representado hoje pelos regimes híbridos, e o individualismo democrático defendido pelas democracias representativas do tipo liberal. Admite-se aqui o caráter controverso da argumentação esposada, porém, como ensinou o próprio Karl Popper, a ciência avança pela proposição de hipóteses que são submetidas a ensaio de teste e erro. 


\title{
THE PLATO POLITICAL LEGACY UNDER THE LIBERAL VIEW OF KARL POPPER: DISCUSSIONS AROUND THE ADVENT OF DEMOCRATIC- AUTOCRATIC REGIMES
}

\begin{abstract}
In literature in philosophy, political theory, and other related fields of knowledge in the human and social sciences, the discussion about the nature of the political legacy left by Plato remains inconclusive. For some authors such as Karl Popper, Platonic thought exhibits undisputed authoritarian elements to the point of decisively influencing a collectivist tradition that contrasts with democratic individualism, the touchstone of representative liberal democracies. After the end of the Cold War, we witnessed the advent of so-called hybrid or illiberal regimes, bringing back to the academic debate normative aspects of liberal criticism addressed to the tradition influenced by Plato's political thought. Through a bibliographical research with a qualitative approach, the objective of this work is to discuss and revise the literature to update the debate about the legacy of Platonic collectivism, having as theoretical reference the liberal thinking of Karl Popper and the emergence of hybrid regimes (democratic authorities). The main conclusion is that the tension between platonic clipping collectivism and democratic individualism, typical of liberalism, remains current as can be seen by the clashes between hybrid regimes and liberal democracies.
\end{abstract}

Keywords: Plato. Totalitarianism. Popper. Liberalism. Hybrid Regimes.

\section{EL LEGADO POLÍTICO DE PLATÓN BAJO LA MIRADA LIBERAL DE KARL POPPER: DISCUSIONES EN TORNO DEL ADVENIMIENTO DE LOS REGÍMENES DEMOCRÁTICO-AUTOCRÁTICOS}

\section{RESUMEN}

En la literatura en filosofía, teoría política y otros campos afines del conocimiento en ciencias humanas y sociales, permanece inconclusa la discusión sobre la naturaleza del legado político dejado por Platón. Para algunos autores como Karl Popper, el pensamiento platónico exhibe indiscutibles elementos autoritarios a punto de influir decisivamente en una tradición colectivista que se contrapone al individualismo democrático, piedra angular de las democracias representativas de tipo liberal. Después del fin de la Guerra Fría, se asistió al surgimiento de los llamados regímenes híbridos o iliberales, trayendo de vuelta al debate académico aspectos normativos de las críticas liberales dirigidas a la tradición influenciada por el pensamiento político de Platón. Por medio de investigación bibliográfica de abordaje cualitativo, el trabajo tiene por objetivo discutir y revisar la literatura para actualizar el debate sobre el legado del colectivismo platónico, teniendo como 
referencial teórico el pensamiento liberal de Karl Popper y el surgimiento de los regímenes híbridos (democrático-autoritarios). La conclusión principal es que la tensión entre el colectivismo de recorte platónico y el individualismo democrático, típico del liberalismo, permanece actual como se puede observar por los choques entre regímenes híbridos y democracias liberales.

Palabras clave: Platón. Totalitarismo. Popper. Liberalismo. Regímenes Híbridos.

1 Popper deve ter sido um dos primeiros pensadores contemporâneos a fazer uma defesa vigorosa seja da accountability vertical (eleições diretas em sufrágios livres), seja da accountability horizontal (exercido por meio de controles institucionais dos governados sobre os governantes). Pelo primeiro controle, pode-se mandar para casa os maus governantes; pelo segundo controle, exercido no período entre eleições, impede-se que os maus governantes causem danos desnecessários ou evitáveis. Note-se que, na primeira metade do século XX, nem todos os filósofos-políticos pensavam assim. Para Joseph Alois Schumpeter, por exemplo, a democracia representativa resumia-se a escolher, por meio de eleições periódicas, qual elite política deveria (nos) governar. Nenhum controle institucional sobre os governantes seria exercido entre as eleições. Assim, em sua obra "Capitalismo, Socialismo e Democracia," Schumpeter declarou que "o princípio da democracia, então, significa apenas que as rédeas do governo devem ser entregues àqueles que contam com maior apoio do que outros indivíduos ou grupos concorrentes" (SCHUMPETER, 2007, p. 337). Ora, a ideia de accountability - seja horizontal, seja vertical - está hoje plenamente assentada no campo do Direito e, sobretudo, da Ciência Política, sendo praticamente impossível conceber o funcionamento das instituições sem sua aplicabilidade efetiva. Além disso, forçoso reconhecer que Popper teve o mérito de antever a importância de tais controles para o exercício e consequente aprimoramento das instituições, como se observa do seguinte trecho de Open Society: "Devemos aprender que, afinal, todos os problemas políticos são problemas institucionais, problemas de arcabouço legal mais que de pessoas, e que o progresso no rumo de maior igualdade só pode ser salvaguardado pelo controle institucional do poder" (POPPER, 1998, p. 169).

2 O relatório da organização Freedom House in the world aponta para uma crise democrática no mundo. Ver: Freedom House in the World (2017).

\section{REFERÊNCIAS}

ARENDT, Hannah. As origens do totalitarismo. São Paulo: Companhia das Letras, 1989. . A condição humana. Rio de Janeiro: Forense Universitária, 2010.

BEDESCHI, Giuseppe. Comunismo. In: BOBBIO, Norberto; MATTEUCCI, Nicola; PASQUINO, Gainfranco (Org.). Dicionário de Política. Brasília: Universidade de Brasília, 1983.

CASSIRER, Ernst. O Mito do Estado. São Paulo: F-QM Editores, 2007.

CORRALES, Javier; HIDALGO, Manuel. El régimen híbrido de Hugo Chávez en transición (2009-2013). Desafios, Bogotá, v. 25, n. 1, p. 47-86, jun. 2013. Disponível em: $<w w w . s c i e l o . o r g . c o / s c i e l o>$. Acesso em: 15 set. 2015.

CORRALES, Javier. A Setback for Chávez. Journal of Democracy, Washington, v. 22, n. 1, p. 122-136, 2011.

ECCEL, Daiane. Hannah Arendt, uma leitora crítica de Platão. Archai, Brasília, n. 8, p. 27-37, jan./jun. 2012. 
ELLNER, Steve. El modelo de la democracia social radical en Venezuela: innovaciones y limitaciones. Centro de Estudios del Desarrollo: Cuadernos del Cendes, Venezuela, v. 29, n. 79, p. 107-133, enero/abr. 2012.

FREEDOM HOUSE IN THE WORLD. Home. Disponível em: < https://freedomhouse. org/report/freedom-world >. Acesso em: 12 ago. 2017.

GAMBOA, Laura. Venezuela Aprofundamento do autoritarismo ou transição para a democracia? Relações Internacionais, Lisboa, n. 52, p. 55-66, dez. 2016.

KORNBLITH, Miriam. Chavismo After Chávez?. Journal of Democracy, Whashington, v. 24, n. 3, p. 47-61, 2013.

LEVINE, Daniel. The Decline and Fall of Democracy in Venezuela: Ten Theses. Bulletin of Latin American Research, v. 21, n. 2, p. 248-268, 2002.

LEVINE, Daniel; MOLINA, Enrique. Calidad de La Democracia en Venezuela. América Latina Hoy, Salamanca, España, v. 62, p. 157-175, 2012.

MERCADO, Alejandro. Ayn Rand (1905-1982). Revista Latinoamericana de Desarrollo Econômico, n. 9, p. 191-207, 2007. Disponível em: <www.scielo.org.bo>. Acesso em: 20 jan. 2015.

PLATÃO. A República. Tradução Carlos Alberto Nunes. 3. ed. Belém: EDUFPA, 2000.

POPPER, Karl Raimund. A Sociedade Aberta e seus Inimigos. Tradução Milton Amado. Belo Horizonte: Itatiaia; São Paulo: Universidade de São Paulo, 1987.

. A Sociedade Aberta e seus Inimigos. Tradução Milton Amado. Belo Horizonte: Itatiaia; São Paulo: Universidade de São Paulo, 1998.

. Autobiografia Intelectual. Tradução Leônidas Hegenberg e Octanny Silveira da Mota. São Paulo: Cultrix, 1977.

RAND, Ayn. O que é capitalismo? 2018. Disponível em: <www.ari.aynrad.org>. Acesso em: 22 jan. 2018.

SCHUMPETER, Joseph. Capitalismo, Socialismo e Democracia. Rio de Janeiro: Fundo de Cultura, 2007.

SHAPIRO, Ian. Os fundamentos morais da política. São Paulo: Martins Fontes, 2006.

STRAUSS, Leo. The City and Man. Chicago: The University of Chicago Press, 2008.

TILLY, Charles. Democracia. Petrópolis: Vozes, 2013.

URRIBARRI, Raul. Venezuela (2015): un régimen híbrido en crisis. Revista de Ciência Política, v. 36, n. 1, p. 365-381, 2016. 